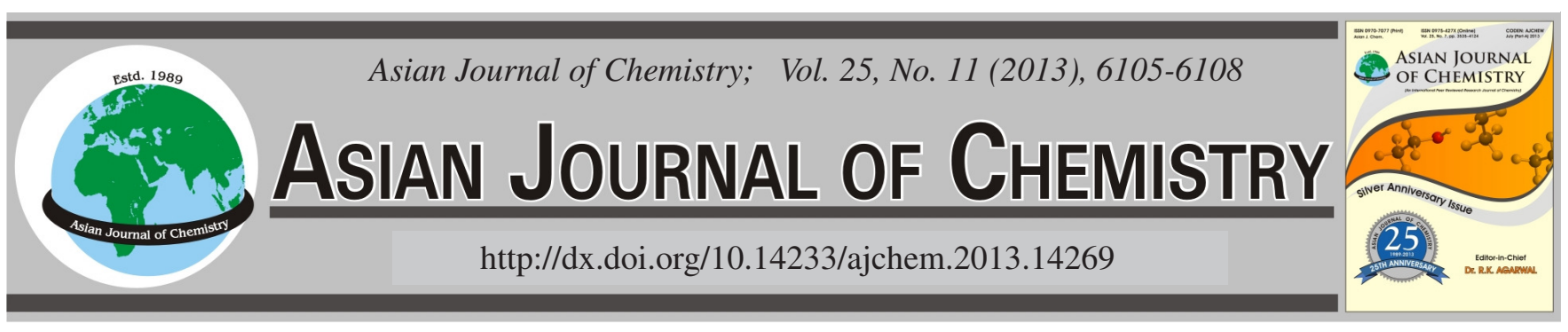

\title{
Microwave Solid Phase Synthesis, Characterization and Antimicrobial Activities of Mononuclear Cobalt(II) Complex with 4-Chloro-benzoic acid 4-[3- (4-chloro-phenyl)-3-hydroxy-acryloyl]-3-hydroxy-phenyl ester
}

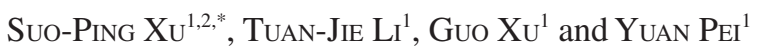

${ }^{1}$ Jiangsu Key Laboratory of Green Synthetic Chemistry for Functional Materials, Jiangsu Normal University, Xuzhou 221116, P.R. China ${ }^{2}$ School of Chemical Engineering and Technology, China University of Mining and Technology, Xuzhou 221008, P.R. China

*Corresponding author: Fax: +86 516 83500366; Tel: +86 516 83403165; E-mail: xsp62@ jsnu.edu.cn

One mononuclear complex has been designed and synthesized by a $\beta$-diketone ligand 4-chloro-benzoic acid 4-[3-(4-chloro-phenyl)-3hydroxy-acryloyl]-3-hydroxy-phenyl ester (L) with $\mathrm{CoCl}_{2} \cdot 6 \mathrm{H}_{2} \mathrm{O}$ in microwave radiation assistance. The complex was characterized by $\mathrm{X}$-ray crystallography, confirming that the central cobalt(II) was coordinated by four oxygens from two $\beta$-diketone ligand and two oxygens from two ethanols. The complex was assayed for in vitro antibacterial (B. subtilis, S. aureus, S. faecalis, P. aeruginosa, E. coli and $E$. cloacae) activities and showed better antimicrobial activity against Gram positive strains than Gram negative strains.

Key Words: Microwave solid phase synthesis, $\beta$-Diketone ligand, Mononuclear cobalt(II) complex, Antibacterial activity.

\section{INTRODUCTION}

$\beta$-Diketones have been important intermediates in organic synthesis. More current research, a strong reactivity of $\beta$ diketones are 1,4-diphenyl-butane-1,3-dione, 1,4-dithiohenebutane-1,3-dione, 1,4-bis-[benzo(1,3)dio-butane]-1,3-dione, 1,4-bis-(3-fluoro-4-methoxy-phenyl)-butane-1,3-dione, 3hydroxy-1,3-diphenyl-propenone, 1,3-di-furan-2-yl-3hydroxy-propenone ${ }^{1-4}$. $\beta$-Diketones and their derivatives also have a wide range of fields in the application of heat stabilizer, luminescence, catalysis, solvent extraction and pharmaceutical $^{5-12}$. Although these methods synthesize reliable routes for the preparation of $\beta$-diketones, most of them follow lengthy procedures and time. Therefore, the development of direct and efficient procedures for these classes of compounds from materials has been the target of synthetic organic chemistry. In this paper, one bidentate $\beta$-diketone ligand, 4-chlorobenzoic acid 4-[3-(4-chloro-phenyl)-3-hydroxy-acryloyl]-3hydroxy-phenyl ester (L), was synthesized by microwave assistance and one mononuclear complex was obtained reacting $\mathrm{L}$ with $\mathrm{CoCl}_{2} \cdot 6 \mathrm{H}_{2} \mathrm{O}$. The complex were assayed for antibacterial activities against three Gram positive bacterial strains (Bacillus subtilis, Staphylococcus aureus and Streptococcus faecalis) and three Gram negative bacterial strains (Escherichia coli, Pseudomonas aeruginosa and Enterobacter cloacae) by the 3-(4,5-dimethyl-2-triazyl)-2,5-diphenyl-2H-tetrazolium bromide (MTT) method.

\section{EXPERIMENTAL}

All chemicals were of reagent grade and used as received. UV spectra were recorded on a U-3000 spectrophotometer. IR spectra were recorded on a Nexus 870 FT-IR. ESI-MS spectra were recorded on a Mariner System 5304 mass spectrometer. Elemental analyses were performed on a CHN-O-rapid instrument and were within $\pm 0.4 \%$ of the theoretical values. Melting points were measured on a Boetius micro melting point apparatus.

Preparation of 4-chloro-benzoic acid 4-[3-(4-chlorophenyl)-3-hydroxy-acryloyl]-3-hydroxy-phenyl ester (L) and its cobalt(II) complex (1): Ligand was designed and synthesized from 2,4-dihydroxyacetophenone and 4-chlorobenzoyl chloride in acetone by microwave assistance ${ }^{13}$. The ligand and $\mathrm{CoCl}_{2} \cdot 6 \mathrm{H}_{2} \mathrm{O}$ were mixed together and microwave radiated $5 \mathrm{~min}$ in $300 \mathrm{~W}$. The nacarat powder was dissolved in water/acetone/DMF(1/1/1) and afforded bis(4-chloro-benzoic acid 4-[3-(4-chloro-phenyl)-3-hydroxy-acryloyl]-3-hydroxyphenyl ester)-bis-water-cobalt(II) (1) (Scheme-I).

Preparation of $\mathbf{L}: \mathrm{K}_{2} \mathrm{CO}_{3}(20 \mathrm{~g})$ was slowly added to a round-bottom-flask containing 2,4-dihydroxyacetophenone (0.02 mol, $3.04 \mathrm{~g})$ and 4-chloro-benzoyl chloride (0.04 mol, $7 \mathrm{~g}$ ) dissolved in acetone $(50 \mathrm{~mL})$. The mixture was microwave-irradiated $(90 \mathrm{~W})$ for $90 \mathrm{~min}$ and then precipitated. After filtration, the yellow solid was washed with acetone $(100 \mathrm{~L})$ and water $(200 \mathrm{~mL})$, dried and recrystallized from ethanol 
<smiles>CC(=O)C1=CCC(O)C=C1O</smiles>

Scheme-I: Synthesis of ligand and its Co(II) complex (1)

acetone (1/1). Yield: $83 \%$, m.p.: $>300{ }^{\circ} \mathrm{C}$. UV $(\lambda \mathrm{nm}): 375$; 251. Selected IR data $\left(\mathrm{KBr}, \mathrm{v}_{\max }, \mathrm{cm}^{-1}\right): 3127.7(\mathrm{~m}), 1744.1$ (s), $1609.1(\mathrm{~s}), 1568.8(\mathrm{~m}), 1515.5(\mathrm{~s}), 1480.9(\mathrm{~s}), 1426.9(\mathrm{~m})$, 1401.6 (s), 1273.4 (s), 1207.0 (m), 1175.9 (m), 1141.3 (s), 1092.2 (s), 1013.8 (s), $970.3(\mathrm{~m}), 845.3(\mathrm{~m}) ;{ }^{1} \mathrm{H}$ NMR $\left(\mathrm{CDCl}_{3}\right)$ $\delta$ ppm: 15.45 (s, 1H), $12.23(\mathrm{~s}, 1 \mathrm{H}), 8.21(\mathrm{~d}, J=7.4 \mathrm{~Hz}, 2 \mathrm{H})$, $7.96(\mathrm{~d}, J=7.0 \mathrm{~Hz}, 2 \mathrm{H}), 7.86(\mathrm{~d}, J=9.2 \mathrm{~Hz}, 1 \mathrm{H}), 7.68(\mathrm{~d}, J=$ $14.6 \mathrm{~Hz}, 1 \mathrm{H}), 7.54(\mathrm{~d}, J=13.2 \mathrm{~Hz}, 2 \mathrm{H}), 7.52(\mathrm{~d}, J=12.8 \mathrm{~Hz}$, 2H), $6.90(\mathrm{~d}, J=2.6,1 \mathrm{H}), 6.80(\mathrm{~s}, 1 \mathrm{H})$. ESI-MS: 429.05 $\left(\mathrm{C}_{22} \mathrm{H}_{15} \mathrm{Cl}_{2} \mathrm{O}_{5}{ }^{+},[\mathrm{M}+\mathrm{H}]^{+}\right)$. Anal. calcd. for $\mathrm{C}_{22} \mathrm{H}_{14} \mathrm{O}_{5} \mathrm{Cl}_{2}(\%)$ : $\mathrm{C}$, 61.56; H, 3.29. Found (\%): C, 61.72; H, 3.24.

Complex 1: The $\beta$-diketone ligand (L) $(2.568 \mathrm{~g}, 6 \mathrm{mmol})$ and $\mathrm{CoCl}_{2} \cdot 6 \mathrm{H}_{2} \mathrm{O}(0.711 \mathrm{~g}, 3 \mathrm{mmol})$ were mixed together and microwave radiated $5 \mathrm{~min}$ in $300 \mathrm{~W}$. The nacarat powder was dissolved in water/acetone/DMF (1/1/1). After standing for 10-15 days, the single crystals of 1 were obtained, were separated by filtration, washed with acetone thrice and dried. Yield: $72 \%$, m.p.: $268-271{ }^{\circ} \mathrm{C}$. UV ( $\lambda$ nm): 377; 256. Selected IR data $\left(\mathrm{KBr}, v_{\max }, \mathrm{cm}^{-1}\right): 3325.7(\mathrm{~m}), 3130.5(\mathrm{~m}), 1736.3(\mathrm{~s})$, $1662.7(\mathrm{~s}), 1592.6(\mathrm{~s}), 1550.7(\mathrm{~s}), 1479.5(\mathrm{~s}), 1456.8(\mathrm{~s}), 1347.2$ (s), $1293.7(\mathrm{~s}), 1207.0(\mathrm{~s}), 1163.0(\mathrm{~m}), 1140.7(\mathrm{~s}), 1111.9(\mathrm{~m})$, 1097.2 (s), 1064.5 (s), 1012.7 (s), 786.5 (s), 754.1 (m). Anal. calcd. for $\mathrm{C}_{47} \mathrm{H}_{37} \mathrm{NO}_{13} \mathrm{CoCl}_{4}(\%)$ : C, 55.05; H, 3.61. Found (\%): C, 55.13; H, 3.58.

Crystal structure determinations and refinements: The crystallographic date for $\mathbf{1}$ was collected on a Bruker Smart 1000 CCD area detector diffractometer equipped with $\mathrm{MoK}_{\alpha}$ $(\lambda=0.71073 \AA$ ) radiation using $\omega$-scan mode. Empirical absorption correction was applied to the data. Unit cell dimensions were obtained with least-squares refinements and all structures were solved by direct methods with SHELXL-97. All non-hydrogen atoms were located from the trial structure and then refined anisotropically. All hydrogens were generated in idealized positions. All calculations were performed with SHELXL-97 programs $^{14}$. Other relevant parameters of the crystal structure are listed in Table-1.

Antimicrobial activity: The antibacterial activity of $\mathrm{L}$ and 1 was tested against B. subtilis, S. aureus, S. faecalis, $P$. aeruginosa, E. coli and E. cloacae using MTT medium. The
TABLE-1

CRYSTALLOGRAPHIC AND EXPERIMENTAL DATA FOR 1

\begin{tabular}{ll}
\hline Compound & $\mathbf{1}$ \\
\hline Empirical formula & $\mathrm{C}_{47} \mathrm{H}_{37} \mathrm{C}_{14} \mathrm{CoNO}_{13}$ \\
Formula weight & 1024.51 \\
Crystal system & Triclinic \\
Space group & $P \overline{1}$ \\
$\mathrm{a}(\AA)$ & $6.9450(5)$ \\
$\mathrm{b}(\AA)$ & $13.11610(12)$ \\
$\mathrm{c}(\AA)$ & $14.84090(13)$ \\
$\alpha\left(^{\circ}\right)$ & $105.812(2)$ \\
$\beta\left(^{\circ}\right)$ & $102.4600(10)$ \\
$\gamma\left({ }^{\circ}\right)$ & $105.326(2)$ \\
$\mathrm{V}\left(\AA^{3}\right)$ & $1192.62(9)$ \\
$\mathrm{Z}$ & 1 \\
$\mathrm{~T}(\mathrm{~K})$ & $298(2)$ \\
Density $\left(\mathrm{g} / \mathrm{cm}^{3}\right)$ & 1.426 \\
$\left.\mu(\mathrm{mm})^{-1}\right)$ & 0.648 \\
$\mathrm{~F}(000)$ & 525 \\
Data/restrains $/$ parameters & $4154 / 0 / 313$ \\
$\theta$ Range $\left({ }^{\circ}\right)$ & 2.65 to 25.02 \\
Reflections collected/ unique & $6320 / 4154$ \\
$\mathrm{R}_{\text {int }}$ & 0.0357 \\
Final R indices $[\mathrm{I}>2 \sigma(\mathrm{I})]$ & $\mathrm{R}_{1}=0.0727, \mathrm{wR}_{2}=0.1858$ \\
$(\Delta \rho)_{\max },(\Delta \rho)_{\min }\left(\mathrm{e} / \AA^{3}\right)$ & 1.157 and -0.256 \\
\hline${ }^{\mathrm{a}} R=\sum|| F_{\mathrm{o}}|-| F_{\mathrm{c}}|/ \Sigma| F_{\mathrm{o}} \mid,{ }^{\mathrm{b}} w R=\left[\Sigma\left[w\left(F_{\mathrm{o}}^{2}-F_{\mathrm{c}}{ }^{2}\right)^{2}\right] / \Sigma\left[w\left(F_{\mathrm{o}}^{2}\right)^{2}\right]\right]^{1 / 2}$ \\
&
\end{tabular}

minimum inhibitory concentrations of the test complexes were determined by a colourimetric method using the dye MTT ${ }^{15}$. A stock solution of the synthesized complex $(50 \mu \mathrm{g} / \mathrm{mL})$ in DMSO was prepared and graded quantities of the test complexes were incorporated in specified quantity of sterilized liquid medium. A specified quantity of the medium containing the complex was poured into microtitration plates. Suspension of the microorganism was prepared to contain approximately $10^{5} \mathrm{cfu} / \mathrm{mL}$ and applied to microtitration plates with serially diluted complexes in DMSO to be tested and incubated at $37^{\circ} \mathrm{C}$ for $24 \mathrm{~h}$ for bacterial. After the minimum inhibitory concentrations were visually determined on each of the microtitration plates, $50 \mu \mathrm{L}$ of PBS (phosphate buffered saline $0.01 \mathrm{~mol} / \mathrm{L}$, pH 7.4: $\mathrm{Na}_{2} \mathrm{HPO}_{4} \cdot 12 \mathrm{H}_{2} \mathrm{O} 2.9 \mathrm{~g}, \mathrm{KH}_{2} \mathrm{PO}_{4} 0.2 \mathrm{~g}, \mathrm{NaCl} 8.0 \mathrm{~g}$, 
$\mathrm{KCl} 0.2 \mathrm{~g}$, distilled water $1000 \mathrm{~mL}$ ) containing $2 \mathrm{mg} / \mathrm{mL}$ of MTT was added to each well. Incubation was continued at room temperature for 4-5 h. The content of each well was removed and $100 \mu \mathrm{L}$ of isopropanol containing $5 \% 1 \mathrm{~mol} / \mathrm{L}$ $\mathrm{HCl}$ was added to extract the dye. After $12 \mathrm{~h}$ of incubation at room temperature, the optical density was measured with a microplate reader at $570 \mathrm{~nm}$. The observed minimum inhibitory concentrations were presented in Table- 2 .

\begin{tabular}{cccc|ccc}
\hline \multicolumn{1}{c}{ TABLE-2 } \\
MINIMUM INHIBITORY CONCENTRATIONS (MICs) \\
OF THE SYNTHETIC COMPOUNDS \\
\hline \multicolumn{6}{c}{ Microorganisms MICs $(\mu \mathrm{g} / \mathrm{mL})$} \\
\cline { 2 - 7 } Compound \\
\cline { 2 - 7 } & \multicolumn{3}{c}{ Gram positive } & \multicolumn{3}{c}{ Gram negative } \\
\cline { 2 - 7 } & subtilis & aureus & faecalis & aeruginosa & coli & cloacae \\
\hline 1 & 6.25 & 6.25 & 3.125 & 12.5 & 6.25 & 12.5 \\
L & 12.5 & 25.0 & 12.5 & 25.0 & 25.0 & 25.0 \\
Penicillin & 1.562 & 1.562 & 1.562 & 6.25 & 6.25 & 3.125 \\
Kanamycin & 0.39 & 1.562 & 3.125 & 3.125 & 3.125 & 1.562 \\
\hline
\end{tabular}

\section{RESULTS AND DISCUSSION}

The complex of the formula $\mathrm{C}_{47} \mathrm{H}_{37} \mathrm{NO}_{13} \mathrm{CoCl}_{4}$ were prepared in moderate yield (72\%). IR spectra of $\beta$-diketone ligand show four bands at $1600-1480 \mathrm{~cm}^{-1}$, characteristic of the mixed modes of vibrations arising from normal coordinates having contributions from $v(\mathrm{C}=\mathrm{O})$ and $v(\mathrm{C}=\mathrm{C})$ of $\beta$-diketone groups ${ }^{16}$. The infrared spectra of complex 1 (KBr pellets) display an intense absorption band at $c a .1662 .7 \mathrm{~cm}^{-1}$ attributable to the $\mathrm{v}(\mathrm{C}=\mathrm{O})$ stretching frequency. This band is shifted ca. $54 \mathrm{~cm}^{-1}$ tower above wavenumbers compared to the ca. $1609 \mathrm{~cm}^{-1}$ attributable to the $\mathrm{v}(\mathrm{C}=\mathrm{O})$ stretching frequency of L. The UV spectra of the complexes display an intense absorption peak at $251-256 \mathrm{~nm}\left(\pi \rightarrow \pi^{*}\right)$ and $375-377 \mathrm{~nm}$ $\left(n \rightarrow \pi^{*}\right)$.

The structure of complex $\mathbf{1}$ were confirmed by a singlecrystal X-ray diffraction and is shown in Figs. 1 and 2. The crystal structure consists of mononuclear complex. The molecular structure of complex $\mathbf{1}$ crystallize in triclinic with space group $\mathrm{P}$; bond distances and angles are provided in Table- 3 . The complex 1 is electronically neutral mononuclear compound. The central metal (Co), on an inversion center, are in pseudo octahedral coordination geometry with two $\mathrm{H}_{2} \mathrm{O}$ occupying both axial positions and oxygen donors from two $\beta$-diketone fragments binding in equatorial positions; each bis- $\beta$ diketonate is essentially planar $^{17}$. The general Co-O bond lengths are in the range 2.012(3)-2.191(4) $\mathrm{A}^{\mathrm{o}}$, unexceptional and similar to the corresponding bonds in other cobalt diketonate complexes ${ }^{17-19}$. As shown in Table-4 intermolecular $\mathrm{H}$-bonds $(\mathrm{O}-\mathrm{H} . . . \mathrm{O})$ formed between adjacent molecules.

\begin{tabular}{|c|c|}
\hline \multicolumn{2}{|c|}{$\begin{array}{c}\text { TABLE-3 } \\
\text { SELECTED BOND LENGTHS }(\AA) \text { AND BOND } \\
\text { ANGLES }\left(^{\circ}\right) \text { OF Co(II) COMPLEX (1) }\end{array}$} \\
\hline Bond & Dist. \\
\hline $\mathrm{Co}(1)-\mathrm{O}(2) \# 1$ & $2.012(3)$ \\
\hline $\mathrm{Co}(1)-\mathrm{O}(1)$ & $2.020(3)$ \\
\hline $\mathrm{Co}(1)-\mathrm{O}(2)$ & $2.012(3)$ \\
\hline $\mathrm{Co}(1)-\mathrm{O}(6)$ & $2.191(4)$ \\
\hline $\mathrm{Co}(1)-\mathrm{O}(1) \# 1$ & $2.020(3)$ \\
\hline $\mathrm{Co}(1)-\mathrm{O}(6) \# 1$ & $2.191(4)$ \\
\hline Angle & $\left({ }^{\circ}\right)$ \\
\hline $\mathrm{O}(2) \# 1-\mathrm{Co}(1)-\mathrm{O}(2)$ & $180.00(11)$ \\
\hline $\mathrm{O}(2) \# 1-\mathrm{Co}(1)-\mathrm{O}(1)$ & $90.61(14)$ \\
\hline $\mathrm{O}(2) \# 1-\mathrm{Co}(1)-\mathrm{O}(6)$ & $87.84(15)$ \\
\hline $\mathrm{O}(1)-\mathrm{Co}(1)-\mathrm{O}(6)$ & $90.85(15)$ \\
\hline $\mathrm{O}(1) \# 1-\mathrm{Co}(1)-\mathrm{O}(6) \# 1$ & $90.85(15)$ \\
\hline $\mathrm{O}(2) \# 1-\mathrm{Co}(1)-\mathrm{O}(1) \# 1$ & $89.39(14)$ \\
\hline $\mathrm{O}(2)-\mathrm{Co}(1)-\mathrm{O}(1)$ & $89.39(14)$ \\
\hline $\mathrm{O}(2)-\mathrm{Co}(1)-\mathrm{O}(6)$ & $92.16(15)$ \\
\hline $\mathrm{O}(2) \# 1-\mathrm{Co}(1)-\mathrm{O}(6) \# 1$ & $92.16(15)$ \\
\hline $\mathrm{O}(1)-\mathrm{Co}(1)-\mathrm{O}(6) \# 1$ & $89.15(15)$ \\
\hline $\mathrm{O}(2)-\mathrm{Co}(1)-\mathrm{O}(1) \# 1$ & $90.61(14)$ \\
\hline $\mathrm{O}(1) \# 1-\mathrm{Co}(1)-\mathrm{O}(1)$ & $180.000(1)$ \\
\hline $\mathrm{O}(1) \# 1-\mathrm{Co}(1)-\mathrm{O}(6)$ & $89.15(15)$ \\
\hline $\mathrm{O}(2)-\mathrm{Co}(1)-\mathrm{O}(6) \# 1$ & $87.84(15)$ \\
\hline $\mathrm{O}(6)-\mathrm{Co}(1)-\mathrm{O}(6) \# 1$ & 180.0 \\
\hline
\end{tabular}

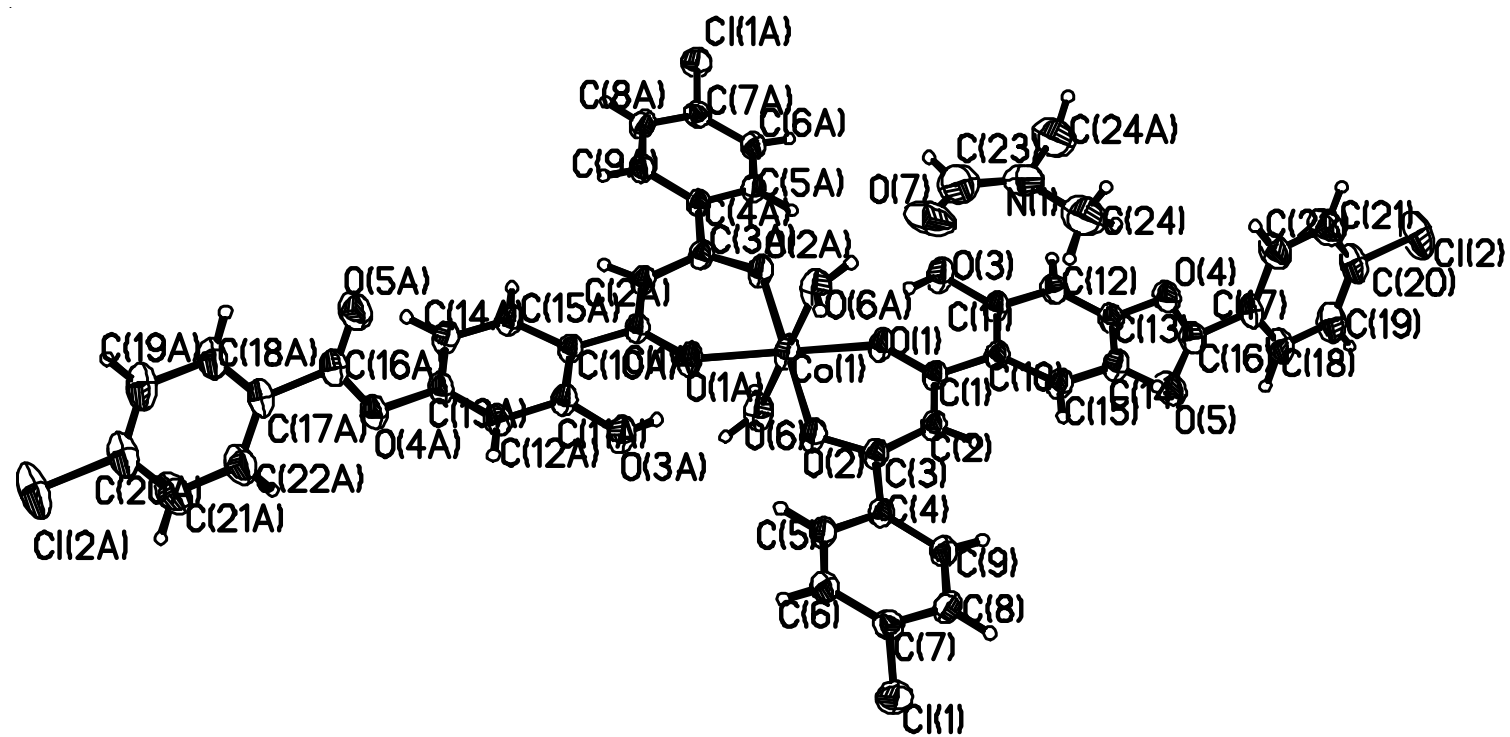

Fig. 1. Crystal structure of complex 1, showing $30 \%$ probability displacement ellipsoids (arbitrary spheres for the $\mathrm{H}$ atoms) 


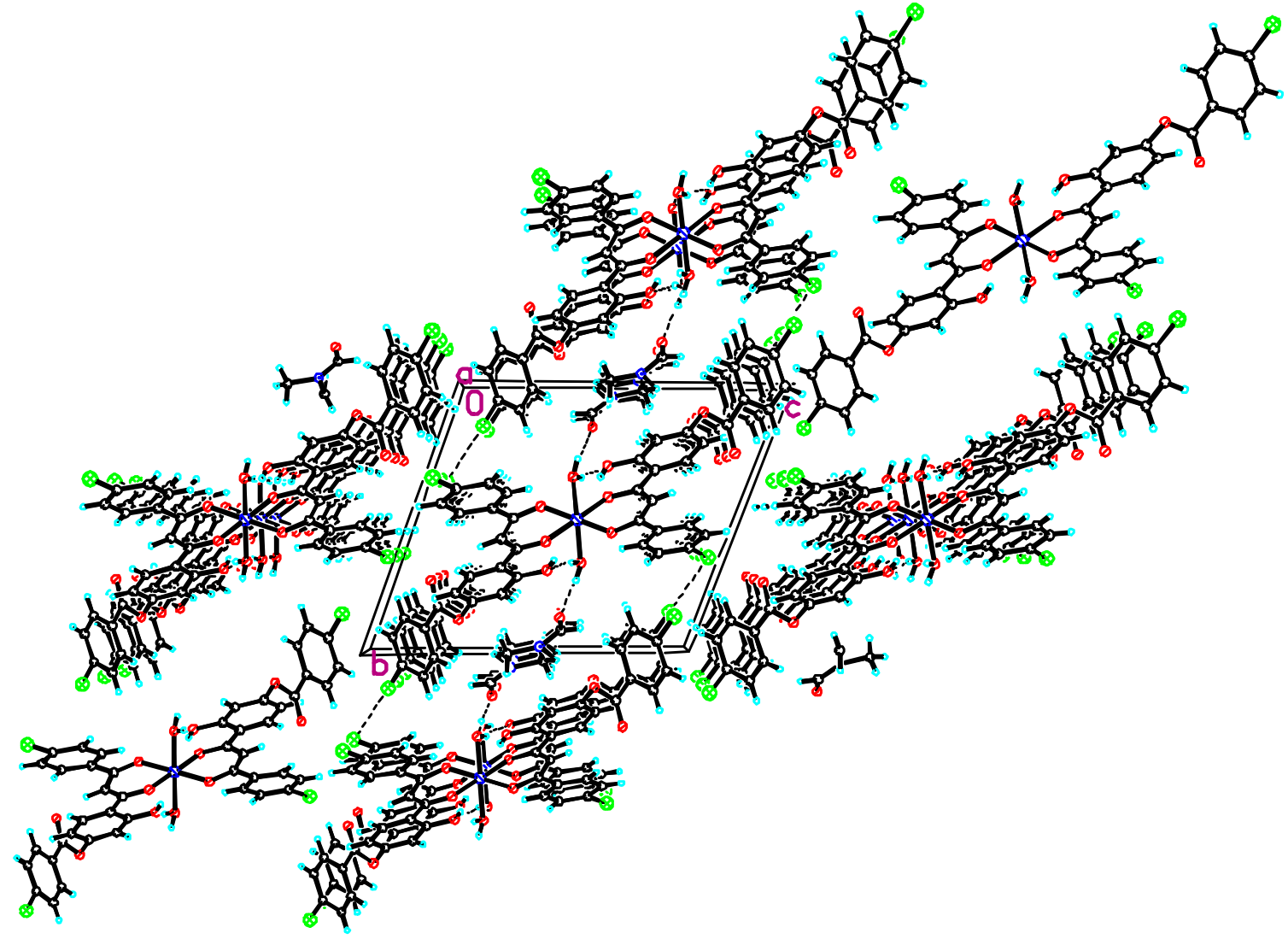

Fig. 2. Packing structure of complex 1 the a-axis

\begin{tabular}{lcccc}
\multicolumn{5}{c}{ TABLE-4 } \\
HYDROGEN BONDS FOR $\mathbf{1}\left[(\AA)\right.$ and $\left.\left({ }^{\circ}\right)\right]$ \\
\hline D-H...A & $\mathrm{d}(\mathrm{D}-\mathrm{H})$ & $\mathrm{d}(\mathrm{H} \ldots \mathrm{A})$ & $\mathrm{d}(\mathrm{D} \ldots \mathrm{A})$ & $<(\mathrm{DHA})$ \\
\hline O3-H3...O1 & 0.82 & 1.74 & 2.4627 & 147 \\
O6-H6(C)...O3 & 0.85 & 2.05 & 2.8809 & 165 \\
O6-H6(D)...O7 & 0.85 & 1.76 & 2.5877 & 164 \\
\hline
\end{tabular}

From minimum inhibitory concentration (MIC) values (Table-2), the complex was more toxic towards Gram positive strains than Gram negative strains when compared to the positive controls penicillin and kanamycin, respectively. The reason may be the difference in the structures of the cell walls ${ }^{20}$. The walls of the Gram negative cells are more complex than those of Gram positive cells. Lipopolysaccharides form an outer lipid membrane and contribute to the complex antigenic specificity of Gram negative cells. Antimicrobial activity of complexes is due to either killing the microbes or inhibiting their multiplication by blocking their active sites ${ }^{21}$. Since the molecular structure is quite similar, the antibacterial activity of $\mathrm{Co}(\mathrm{II})$ complex (1) is quite similar.

\section{ACKNOWLEDGEMENTS}

The work was co-financed by grants from a Project Funded by the Priority Academic Program Development of Jiangsu Higher Education Institutions, China.

\section{REFERENCES}

1. M. Sakkarapalayam and S.A. Indrapal, J. Org. Chem., 71, 349 (2006)

2. L. Gong, R. Leung-Toung and T.T. Tidwell, J. Org. Chem., 55, 3634 (1990).
3. G. Blaskó, L. Xun and G.A. Cordell, J. Nat. Prod., 51, 60 (1988).

4. A.R. Katritzky, Z.-Q. Wang, M.-Y. Wang, C.R. Wilkerson, C.D. Hall and N.G. Akhmedov, J. Org. Chem., 69, 6617 (2004).

5. S.-P. Xu, B.-F. Ruan, Q.-Y. Pan and R.-T. Hu, J. Coord. Chem., 64, 2489 (2011).

6. R. Kumar and Y.C. Joshi, J. Serb. Chem. Soc., 73, 937 (2008).

7. L. Li, P.-J. Cai, D. Xu, Q.-X. Guo and S. Xue, J. Org. Chem., 72, 8131 (2007).

8. K. Singletary, C. MacDonald, M. Iovinelli, C. Fisher and M. Wallig, Carcinogenesis, 19, 1039 (1998).

9. X. Zhang, Z.-C. Li, N. Xu, K.-B. Li, S. Lin, F.-Z. Lu, F.-S. Du and F.-M. Li, Tetrahedron Lett., 47, 2623 (2006).

10. D. Teixeira, T. Lalot, M. Brigodiot and E. Maréchal, Macromolecules, 32, 70 (1999).

11. A. Joshi, S. Verma, R.B. Gaur and R.R. Sharma, Bioinorg. Chem. Appl., 3, 201 (2005).

12. C.L. Modenbach, F.R. Fronczek, E.W. Berg and T.C. Taylor, Inorg. Chem., 22, 4083 (1983)

13. G. Xu, S.-P. Xu, J.-X. Shu, Y. Pei, W.-X. Su and J. Xuzhou, Norm. Univ.: Nat. Sci. Ed., 29, 66 (2011).

14. G.M. Sheldrick SHELXL-97, Program for the Refinement of Crystal Structures, University of Göttingen, Germany (1977).

15. J. Meletiadis, J.F. Meis, J.W. Mouton, J.P. Donnelly and P.E. Verweij, J. Clin. Microbiol., 38, 2949 (2000).

16. K. Nakamato, Infrared Spectra of Inorganic and Coordination Compounds, Wiley, New York (1964).

17. S.-P. Xu, B.-F. Ruan, Q.-Y. Pan and R.-T. Hu, J. Coord. Chem., 64, 2489 (2011).

18. J.-M. Li, J.-Z. Li, H.-Q. Zhang and L.-Y. Xu, Inorg. Chem. Commun., 13, 573 (2010).

19. J.K. Clegg, D.J. Bray, K. Gloe, K. Gloe, M.J. Hayter, K.A. Jolliffe, G.A. Lawrance, G.V. Meehan, J.C. McMurtrie, L.F. Lindoy and M. Wenzel, J. Chem. Soc., Dalton Trans., 1719 (2007).

20. R.V. Singh, P. Chaudhary, S. Chauhan and M. Swami, Spectrochim. Acta A, 72, 260 (2009).

21. M. Nath, S. Pokharia, X. Song, G. Eng, M. Gielen, M. Kemmer, M. Biesemans, R. Willem and D. De Vos, Appl. Organomet. Chem., 17, 305 (2003). 